\title{
Influencing Factors and Evaluation Criteria of Pile Foundation Settlement in Karst Area
}

\author{
Anbing HU \\ Highway Administration of Huizhou Municipality \\ Huizhou, China \\ E-mail:188618092@qq.com
}

\author{
Shanglin QIN \\ Institute of Rock and Soil Mechanics \\ Chinese Academy of Sciences \\ Wuhan, China \\ E-mail: slqin@whrsm.ac.cn
}

\author{
Hongming LUO \\ Institute of Rock and Soil Mechanics \\ Chinese Academy of Sciences \\ Wuhan, China
}

\begin{abstract}
In karst area, lots of piles through several caves and then supporting in a cave roof, thus forming more complex pile-soil-cave interaction. Research on the pile foundation settlement in beaded karst region, has strong theoretical and engineering significance to further improve the design theory of the pile foundation and guide the foundation design and construction. In this paper, it is found that in the stage of the construction of pile foundation, cave has little effect on the settlement. Under the upper load, the impact of the cave quantity and spacing is not significant, and the impact of the cave width is significant. In the effect of consolidation of the cave fillings, the cave has the greatest influence on the settlement. Overall speaking, the cave size has the greatest impact on the total settlement of the pile foundation, the cave quantity is the second, and the cave spacing has the minimal impact.
\end{abstract}

Keywords-karst; pile foundation; settlement; influence

\section{INTRODUCTION}

With the development of the infrastructure in China, more and more projects are located in the karst area[1-2]. Although there are many researches about the effect of karst cave on the pile bearing characteristics and the cave stability, but many of the existing researches is focus on pile supported on a single cave roof, very few consider the situation of the pile through several caves (i.e. string-beaded caves)[3-5]. In fact, in karst area, lots of piles through several caves and then supporting in a cave roof, thus forming more complex pile-soil-cave interaction, the current pile foundation design codes in this regard are failed to provide effective design calculation method[6-9]. Therefore, research on the pile foundation settlement in beaded karst region, has strong theoretical and engineering significance to further improve the design theory of the pile foundation and guide the foundation design and construction.

\section{ANALYSIS METHOD}

Use finite element numerical calculation method, considering the pile foundation construction load, the pile upper load and the influence factors of the karst, the calculation is divided into 4 stages.

The first stage: the simulation of gravity, calculate the initial stress of the axisymmetric numerical model.

The second stage: the simulation of pile foundation construction, calculate the deformation and stress, the main load is pile weight.

The third stage: apply the upper load $158.7 \mathrm{~T}$, calculate the stress and deformation under the action of external load.

The fourth stage: reduce the elastic modulus of the filling material (reduced by 70\%), calculate the influence of the soft filler consolidation settlement on the stress and deformation of the pile.

\section{ANALYSIS SCHEME}

The analysis can be divided into the following conditions: Combination conditions 1: The number of karst cave is respectively $1,2,3$, the diameter is $3.6 \mathrm{~m}$, the spacing is $1.8 \mathrm{~m}$;

Combination condition 2: The number of karst cave is 3, the height is $3.6 \mathrm{~m}$, the width is respectively $2.4 \mathrm{~m}, 3.6 \mathrm{~m}$, $4.8 \mathrm{~m}$, the spacing is $1.8 \mathrm{~m}$;

Combination condition 3: The number of karst cave is 3, the diameter is $3.6 \mathrm{~m}$, the spacing is respectively $0.6 \mathrm{~m}, 1.2 \mathrm{~m}$, $1.8 \mathrm{~m}$.

\section{ANALYSIS OF THE INFLUENCING FACTORS OF THE Pile Foundation SETTLEMENT}

The settlement deformation of pile influenced by the cave quantity under the different load stages of pile construction, upper load and cave effect is shown in Fig. 1. 


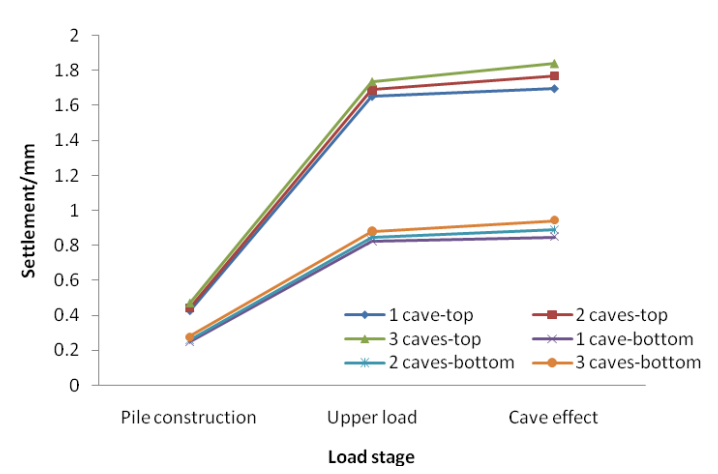

Figure 1. The settlement of pile influenced by the cave quantity under different load stages

In the stage of the construction of pile foundation, cave quantity has little effect on the settlement caused by the load of pile weight, the settlement at the top of the pile is $0.43 \sim 0.47 \mathrm{~mm}$, and it is $0.25 \sim 0.28 \mathrm{~mm}$ at the bottom, the settlement of 3 caves is respectively $0.02 \mathrm{~mm}$ and $0.04 \mathrm{~mm}$ larger than that of 2 caves and 1 cave. Under the upper load, the total settlement the differential settlement of the top and the bottom of the pile increase significantly, but the impact of the cave quantity is still not significant, the top settlement increases to $1.65 \sim 1.73 \mathrm{~mm}$, the bottom settlement increases to $0.82 \sim 0.88 \mathrm{~mm}$, the settlement of 3 caves is respectively $0.03 \mathrm{~mm}$ and $0.08 \mathrm{~mm}$ larger than that of 2 caves and 1 cave. In the effect of consolidation of the cave fillings, the increment the total settlement the differential settlement of the top and the bottom of the pile are very small, the top settlement is $1.70 \sim 1.84 \mathrm{~mm}$, the bottom settlement is $0.85 \sim 0.94 \mathrm{~mm}$, at this time, the cave quantity has the largest influence on the settlement, the settlement of 3 caves is respectively $0.07 \mathrm{~mm}$ and $0.14 \mathrm{~mm}$ larger than that of 2 caves and 1 cave.

The settlement deformation of pile influenced by the cave width under the different load stages of pile construction, upper load and cave effect is shown in Fig. 2.

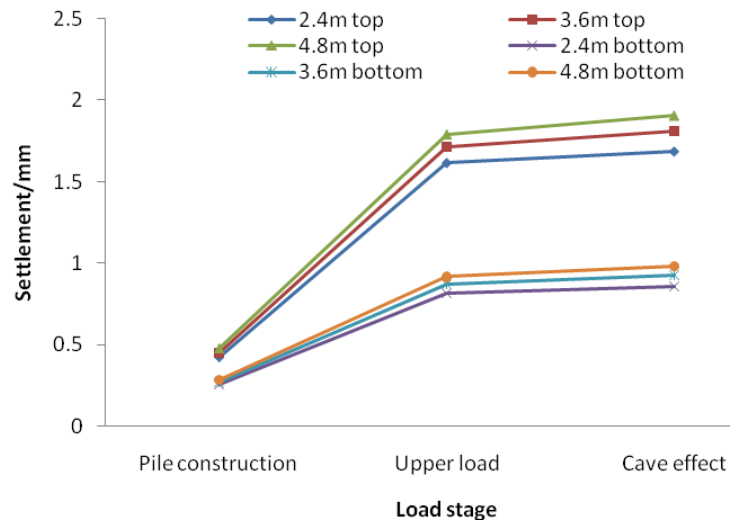

Figure 2. The settlement of pile influenced by the cave width under different load stages

In the stage of the construction of pile foundation, cave width has little effect on the settlement caused by the load of pile weight, the settlement at the top of the pile is
$0.42 \sim 0.48 \mathrm{~mm}$, and it is $0.26 \sim 0.29 \mathrm{~mm}$ at the bottom, the settlement of $4.8 \mathrm{~m}$ width is respectively $0.03 \mathrm{~mm}$ and $0.06 \mathrm{~mm}$ larger than that of $3.6 \mathrm{~m}$ width and $2.4 \mathrm{~m}$ width. Under the upper load, the total settlement the differential settlement of the top and the bottom of the pile increase significantly, and the impact of the cave width is significant, the top settlement increases to $1.62 \sim 1.79 \mathrm{~mm}$, the bottom settlement increases to $0.82 \sim 0.92 \mathrm{~mm}$, the settlement of $4.8 \mathrm{~m}$ width is respectively $0.08 \mathrm{~mm}$ and $0.17 \mathrm{~mm}$ larger than that of $3.6 \mathrm{~m}$ width and $2.4 \mathrm{~m}$ width. In the effect of consolidation of the cave fillings, the increment the total settlement the differential settlement of the top and the bottom of the pile are very small, the top settlement is $1.69 \sim 1.91 \mathrm{~mm}$, the bottom settlement is $0.86 \sim 0.98 \mathrm{~mm}$, at this time, the cave quantity has the largest influence on the settlement, the settlement of $4.8 \mathrm{~m}$ width is respectively $0.10 \mathrm{~mm}$ and $0.22 \mathrm{~mm}$ larger than that of $3.6 \mathrm{~m}$ width and $2.4 \mathrm{~m}$ width.

The settlement deformation of pile influenced by the cave spacing under the different load stages of pile construction, upper load and cave effect is shown in Fig. 3.

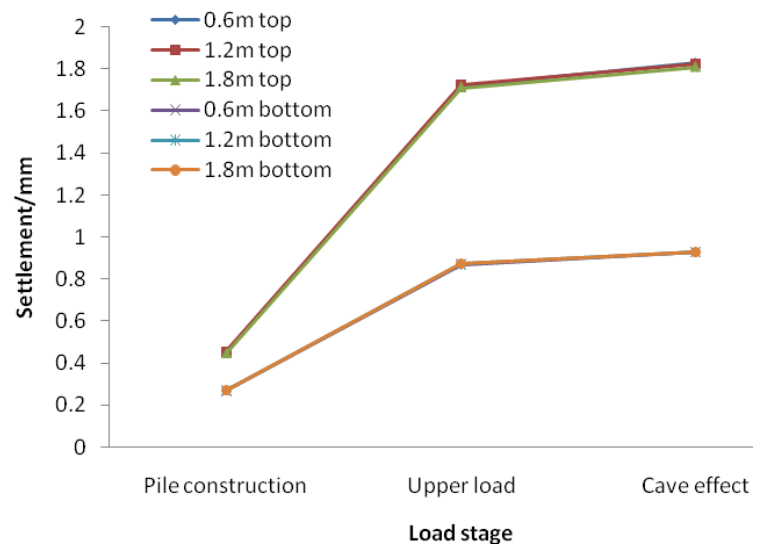

Figure 3. The settlement of pile influenced by the cave spacing under different load stages

In the stage of the construction of pile foundation, cave spacing has little effect on the settlement caused by the load of pile weight, the settlement at the top of the pile is $0.45 \sim 0.46 \mathrm{~mm}$, and it is $0.27 \mathrm{~mm}$ at the bottom, the settlement of $0.6 \mathrm{~m}$ spacing is not more than $0.01 \mathrm{~mm}$ larger than that of $1.2 \mathrm{~m}$ spacing and $1.8 \mathrm{~m}$ spcing. Under the upper load, the total settlement the differential settlement of the top and the bottom of the pile increase significantly, but the impact of the cave spacing is still not significant, the top settlement increases to $1.71 \sim 1.72 \mathrm{~mm}$, the bottom settlement increases to $0.87 \mathrm{~mm}$, the settlement of $0.6 \mathrm{~m}$ spacing is not more than $0.01 \mathrm{~mm}$ larger than that of $1.2 \mathrm{~m}$ spacing and $1.8 \mathrm{~m}$ spcing. In the effect of consolidation of the cave fillings, the increment the total settlement the differential settlement of the top and the bottom of the pile are very small, the top settlement is $1.81 \sim 1.83 \mathrm{~mm}$, the bottom settlement is $0.93 \mathrm{~mm}$, the settlement of $0.6 \mathrm{~m}$ spacing is respectively $0.01 \mathrm{~mm}$ and $0.02 \mathrm{~mm}$ larger than that of $1.2 \mathrm{~m}$ spacing and $1.8 \mathrm{~m}$ spacing.

Fig. 4 shows the variation law of the total settlement of the pile foundation in different load stages under different karst conditions. 


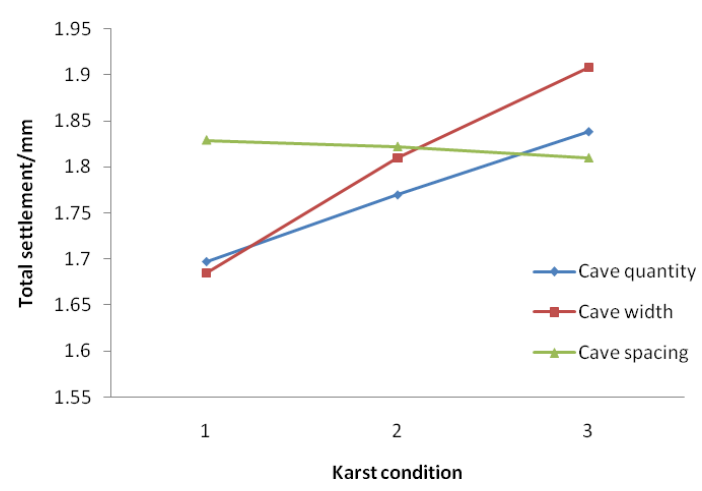

(a) Karst condition

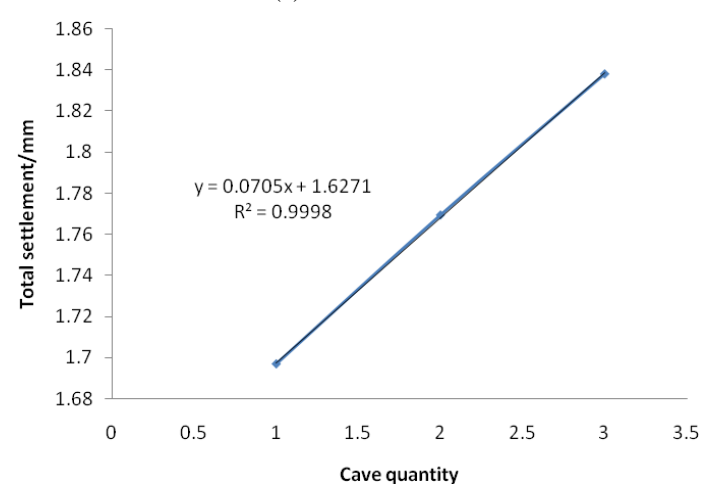

(b) Cave quantity

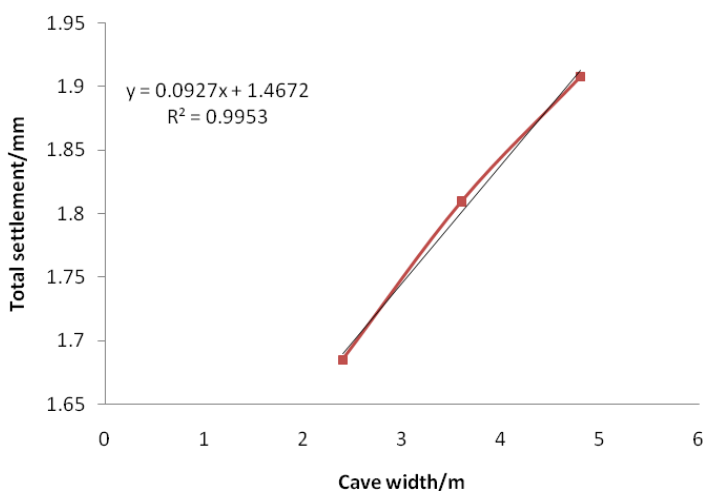

(c) Cave size

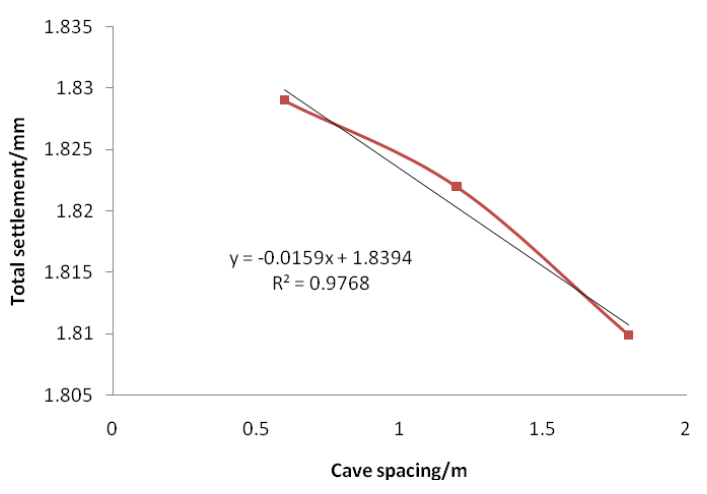

(d) Cave spacing

Figure 4. The total settlement of pile under the influence of karst cave (Karst condition 1,2,3 respectively represents the cave number 1,2,3; the cave width $2.4,3.6,4.8 \mathrm{~m}$; the cave spacing $1.8,1.2,0.6 \mathrm{~m}$ )
It can be seen from Fig. 4(a), with the increase of the number of karst cave, the size of the cave and the decrease of the distance between the karst cave, the total settlement of pile caused by the impact of the karst cave is gradually increasing.

The cave size has the greatest influence on the total settlement of pile, under the same conditions of 3 caves, the cave width increases from $2.4 \mathrm{~m}$ to $4.8 \mathrm{~m}$, the total settlement of pile increases from $1.685 \mathrm{~mm}$ to $1.908 \mathrm{~mm}$, in the case of a $100 \%$ increase in the size of karst cave, the total settlement of pile increases $13.23 \%$.

The cave quantity has great influence on the total settlement of pile, which increases from $1.697 \mathrm{~mm}$ of one cave to $1.838 \mathrm{~mm}$ of three caves, in the case of a $200 \%$ increase in the number of karst cave, the total settlement of pile increases $8.31 \%$.

The cave spacing has minimum influence on the total settlement of pile, under the same conditions of 3 caves, the cave spacing reduces from $1.8 \mathrm{~m}$ to $0.6 \mathrm{~m}$, the total settlement of pile increases from $1.810 \mathrm{~mm}$ to $1.829 \mathrm{~mm}$, karst spacing decreases by $66.7 \%$, the total settlement of pile only increases $1.05 \%$.

It can be seen from Fig. 4 (b), with the increase of the number of karst cave, the total settlement of pile increases, use the linear function to fit the empirical formula, the correlation coefficient reaches 0.999 , the fitting formula is

$$
s=0.0705 m+1.6271
$$

where, $m$ is the cave quantity.

It can be seen from Fig. 4 (c), with the increase of the width of karst cave, the total settlement of pile increases, use the linear function to fit the empirical formula, the correlation coefficient reaches 0.998 , the fitting formula is

$$
s=0.0927 b+1.4672
$$

where, $b$ is the cave width (m).

It can be seen from Fig. 4 (d), with the decrease of the spacing of karst cave, the total settlement of pile increases, use the linear function to fit the empirical formula, the correlation coefficient reaches 0.988 , the fitting formula is

$$
s=-0.0159 d+1.8394
$$

where, $d$ is the cave spacing (m).

It can be known from the comparison of the slopes of three empirical formulas, the slope of the cave size formula is maximum, indicating that the cave size has the greatest impact on the total settlement of the pile foundation, the cave quantity is the second, and the cave spacing has the minimal impact.

\section{Effect Evaluation of the Beaded Cave on The Total SetTlement of The Pile Foundation}

Using the total settlement of the pile to evaluate the effect of karst on the pile foundation, the control indexes can be seen in Tab. 1. 
TABle I. The Pile Total Settlement Evaluation IndeX

\begin{tabular}{|c|c|c|c|}
\hline $\begin{array}{c}\text { Total settlement } \\
(\mathrm{mm})\end{array}$ & Cave quantity & $\begin{array}{c}\text { Cave width } \\
\text { (m) }\end{array}$ & $\begin{array}{c}\text { Cave spacing } \\
\text { (m) }\end{array}$ \\
\hline $1.6 \sim 1.7$ & 1 & $0.5 \sim 2.5$ & $>8.5$ \\
\hline $1.7 \sim 1.8$ & $1 \sim 3$ & $2.5 \sim 3.5$ & $2.5 \sim 8.5$ \\
\hline $1.8 \sim 1.9$ & $3 \sim 4$ & $3.5 \sim 4.7$ & $0.5 \sim 2.5$ \\
\hline $1.9 \sim 2.0$ & $4 \sim 5$ & $4.7 \sim 5.7$ & \multirow{5}{*}{ 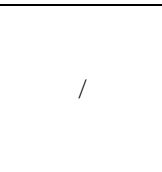 } \\
\hline $2.0 \sim 2.1$ & $5 \sim 7$ & $5.7 \sim 6.8$ & \\
\hline $2.1 \sim 2.2$ & $7 \sim 8$ & $6.8 \sim 7.9$ & \\
\hline $2.2 \sim 2.3$ & $8 \sim 10$ & $7.9 \sim 9.0$ & \\
\hline 2.4 & 11 & 10.0 & \\
\hline
\end{tabular}

\section{CONCLUSION}

Use finite element numerical calculation method, calculation is taken considering the pile foundation construction load, the pile upper load and the influence factors of the karst. It is found that the cave size has the greatest impact on the total settlement of the pile foundation, the cave quantity is the second, and the cave spacing has the minimal impact. In the case of a $100 \%$ increase in the size of karst cave, the total settlement of pile increases $13.23 \%$, while karst spacing decreases by $66.7 \%$, the total settlement of pile only increases $1.05 \%$. And the control indexes are given when using the total settlement of the pile to evaluate the effect of karst on the pile foundation.

\section{ACKNOWLEDGMENT}

This work was financially supported by the Guangdong traffic science and technology project (201407).

\section{REFERENCES}

[1] Jayasinghe, L. B., Thambiratnam, D. P., Perera, N., \& Jayasooriya, J. H. A. R. "Blast response and failure analysis of pile foundations subjected to surface explosion", Engineering Failure Analysis, vol. 39, Aug. 2014, pp. 41-54.

[2] Yi, J., He, G. J., Liu, S. S., Li, Z. Y., \& Zheng, Z. E., "Construction method and numerical analysis on the bearing capacity of the large diameter and abyssal pile located in complex karst area", Advanced Materials Research, vols. 639-640, Jan. 2013, pp. 688-693, doi: 10.4028/www.scientific.net/AMR.639-640.688.

[3] Peiris, T., Thambiratnam, D., Perera, N., \& Gallage, C. "Soil-pile interaction of pile embedded in deep-layered marine sediment under seismic excitation", Structural Engineering International, vol. 24, Nov. 2014, pp. 521-531.

[4] Zheng, W. G., Xie, Y. C., \& Xue, X. B., "Selection of pile foundations in karst areas", Chinese Journal of Geotechnical Engineering, vol. 33, Oct. 2014, pp. 404-407.

[5] Bettiol, G., Ceccato, F., Pigouni, A. E., Modena, C., \& Simonini, P. "Effect on the structure in elevation of wood deterioration on smallpile foundation: numerical analyses", International Journal of Architectural Heritage, vol. 10, Mar. 2014, pp. 44-54.

[6] Lodigina, N., \& Sharapov, R., "Calculation of pile foundations at the karst areas", International Conference on Mechanical Engineering, Automation and Control Systems, IEEE. 2014.

[7] Hua, S., \& Engineering, D. O., "Numerical simulation research on the stability of transmission tower pile foundations in a karst area of guangdong province", Carsologica Sinica, Vol. 33, Jan. 2014, pp. 4450.

[8] Sun, Y., Zhang, Z., \& Zhang, H., "Analysis on parameter sensitivity of pile foundations stability in karst areas based on the theory of grey relation", Chinese Journal of Underground Space \& Engineering, Vol. 9, Apr. 2013, pp.297-303.

[9] Medina, C., Padrón, L. A., Aznárez, J. J., Santana, A., \& Maeso, O. "Kinematic interaction factors of deep foundations with inclined piles", Earthquake Engineering \& Structural Dynamics, vol. 43, Oct. 2014, pp. 2035-2050. 